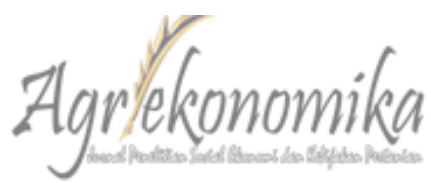

Jurnal Sosial Ekonomi dan Kebijakan Pertanian

http://journal.trunojoyo.ac.id/agriekonomika

Agriekonomika Volume 7, Nomor 1, 2018

\title{
Lebak Swamp Typology and Rice Production Potency in Jakabaring South Sumatra
}

\author{
Elisa Wildayana and M. Edi Armanto \\ Faculty of Agriculture, Sriwijaya University South Sumatra Indonesia \\ Received: Desember 2016; Accepted: Maret 2018; Published: April 2018 \\ DOI: http://dx.doi.org/10.21107/agriekonomika.v7i1.2513
}

\begin{abstract}
The economic and regional development of Palembang has caused land conversion, which was originally as agricultural land and has been converted into non-agricultural activities. The research aimed to compare the typology of lebak swamps and potential rice production before and after the landfilling. Spatial data were obtained using Landsat imagery interpretation in 1987 and 2016. Attribute data was collected using questionnaires and sampling technique was done using disproportionate random sampling method. Typologies of lebak swamps consisted of lebak lebung, deep lebak, middle lebak, levee lebak, shallow lebak and dry land. After landfilling, dry land covers an area of 1,964 ha (72.73\%), while the lebak swamp was decreased by approximately 736 ha (27.27\%). Before landfilling, soil orders were found based on its dominance, namely Histosols, Entisols, Inceptisols and Gelisols. After landfilling, composition of soil order was dominated by Entisol, Inceptisol, Gelisols and Histosols. Before landfilling rice yields were produced about 3,240 tons of milled dry rice (MDR)/year, and rice production potency is now only about 506.25 tons of MDR/year.
\end{abstract}

Keywords: Lebak swamp, Typology, Rice, Potency, South Sumatra

\section{INTRODUCTION}

Lebak swamp (freshwater swamp or back swamp or inland swamp) is defined as a region or a plain located along left and right positions of the rivers and characterized by a poor drainage system (Sjarkowi et al., 2007; Zahri et al., 2018). It is mentioned as back swamp because the plain extends away from the sea or the rivers. In wet seasons, lebak swamp becomes flooded plains as it gets water overflow of major rivers and rainfall as well as its normally stagnant water is very difficult to drain. In dry seasons, the stagnant water shrinks because most of the water flows back into the river and the plains become dry. At dry seasons, lebak swamp will be planted by farmers to grow usually rice and cereals. Besides rice, lebak swamp is utilized for fishing activities, livestock and others (Armanto, 2014).

Lebak swamp in South Sumatra province cultivated as the agricultural area is less than $30 \%$ and is distributed along the Musi River and Ogan River. In achieving food self-sufficiency, lebak swamp is able to provide the highest rice productions $(30 \%)$ compared to technically irrigated rice fields $(27 \%)$, tidal rice fields $(25 \%)$, and other rice fields (18\%) of the total rice production in South Sumatra (Armanto et al., 2013). Lebak swamp for agriculture can still be improved, not only for rice production, but also for fisheries and plantations as well as other uses (Adriani et al., 2018; Wildayana, 2018a; 2018b).

Jakabaring is an adjoining area directly and located in the southern part of Palembang and is mostly occupied by lebak swamp. Thus Jakabaring is a supporting area and at the same time experiencing direct pressure due to the population increase and economic development of Palembang and its surroundings. Thus land conversion in Jakabaring is very difficult to be avoided, and the government

\footnotetext{
Corresponding author:

Address : Komplek Kenten Permai Blok A No 10 RT 20/004 Palembang (30114), SUMSEL.

Email : ewildayana@unsri.ac.id

Phone : 08127338950
} 
has developed some public facilities in this area, among other international sport center, super and hyper markets, shopping centers, residential centers and others (Wildayana, 2017; Junedi et al., 2017).

In the beginning Jakabaring belongs to lebak swamp area for agricultural purposes (Wildayana, 2014). In line with the economic development, Jakabaring has been allocated not only for agriculture, but also for non-agricultural areas. In order to utilize it optimally, it has been reclaimed by landfilling. The landfilling materials come originally from the Musi river, which consist of small rock, sand and mud soil.

We need to take some lessonlearnt from this case especially in terms of agriculture (Sarno et al., 2017; Ningsih et al., 2017). The lessons-learnt will help us to analyze and to examine with care when lebak swamp will be converted to other non-agricultural purposes (Wildayana, 2015). Therefore, this research aimed to compare lebak swamp typology and rice production potency before and after landfilling in Jakabaring South Sumatra.

\section{METHODOLOGY}

The research approach is done in two ways, namely for spatial data collection and data attribute. Spatial data were ob- tained using Landsat imagery interpretation in 1987 and 2016. The interpretation of the research area was supported by thematic maps, topographic maps of $1: 50,000$ scale, landuse maps with scale of 1: 250,000, swamp maps with scale of $1: 500,000$ and followed by calculation of area and distribution of natural phenomena by planimetric method (Figure 1).

The soil classification is based on the Soil Survey Staff (2014) manual book and the measurement of the rice production was done by plots of squares (size 10$10 \mathrm{~m}$ ) and multiplied by the whole planting area. The research method for attribute data was using field survey. Determination of sampling technique was done by using disproportionate random sampling. The total number of respondents (mostly farmers) was 120 respondents. Recording of respondent data was done by interview using questionnaire. Data attribute was processed and analyzed by using SPSS program and displayed in the form of narration, description and tables.

\section{RESULTS AND DISCUSSION}

Research results and discussion focuses on the aspect of knowing how the lebak typology and compare between the condition of lebak before the landfilling (1988)

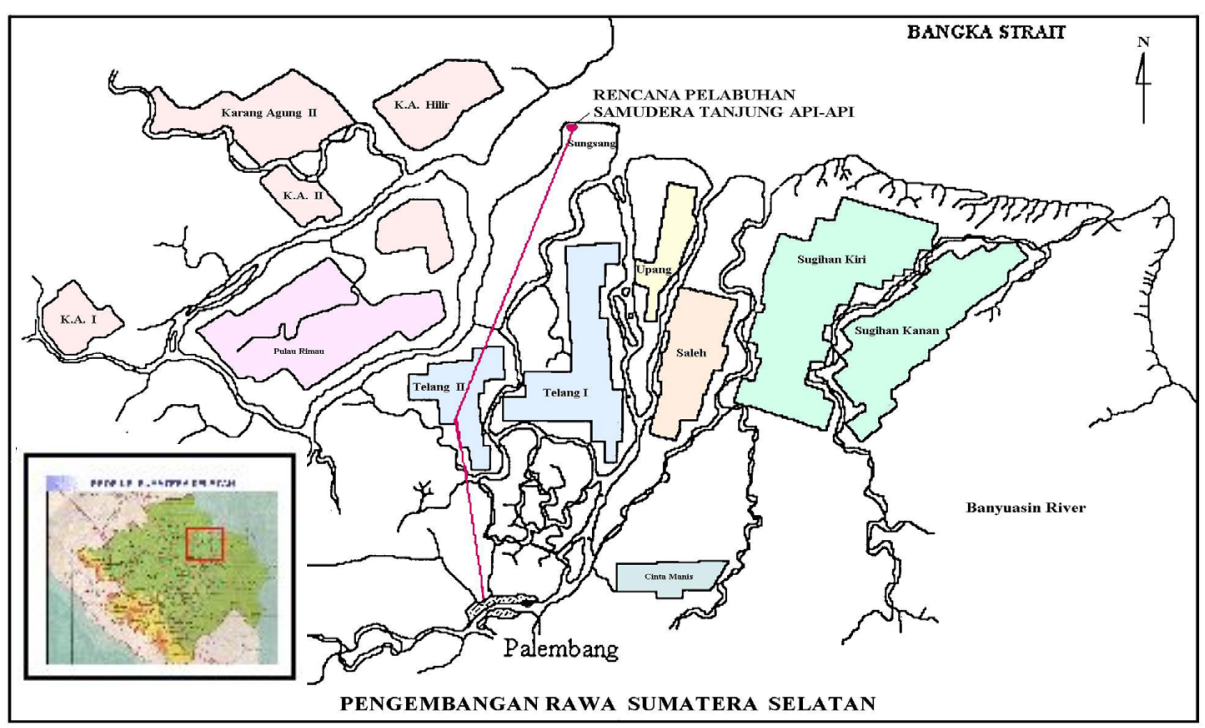

Source: Google Map, 2017

Figure 1

Research Site in Jakabaring Palembang (Google web) 
with existing condition (2017). Knowing the lebak typology and comparing the impact of landfilling is important to evaluate the extent of changes in occurring to the lebak swamp.

\section{Lebak Swamp Typology}

The lebak swamp can be divided into six typologies, namely lebak lebung; deep lebak; middle lebak; levee lebak; shallow lebak and dry land (Table 1). Typology of the lebak ecosystem is an important part in the formation of socio-economic and cultural local communities who live and settle in the lebak ecosystem. Functions of lebak swamp are not only as business and residential areas, but also as water resources, washing, domestic need of water as well as social and cultural interactions.

Lebak lebung is a depression in swampy areas and is always flooded, water level $>150 \mathrm{~cm}$, and peaty $50-100 \mathrm{~cm}$. In general, lebak lebung often accumulate freshwater fish, especially at low tide during the dry season. Lebak lebung is formed in two ways, namely naturally, especially in the depression area, and man-made with the purpose for collecting freshwater fish in the dry season. Lebak lebung is utilized as a major business area for the community and as government revenue (PAD) by lebak lebung auction. PAD varies according to the potential of each region, the circumstances of each district, for example in district of MUBA and OKI, their revenue earned from the lebak lebung auction around Rp 2.5 billion/year. Results of lebak lebung is obtained various types of fish, including fish for consumption and ornamental fish, for example belida fish (Notopterus $s p$. ), arowana or tangkeleso fish (Scleropages formasus), sumpit fish (Taxotes $s p$.), botia fish (Botia sp.), serandang fish (Ophiocephalus pleurophthalmus) and any others. Types of consumption fishes, such as catfish, sepat fish, betok fish, patin fish, tembakang fish, toman fish, baung fish and others.

Deep lebak is a part of swampy area that is much lower than middle lebak. It is flooded 6-9 months/year, water level $100-150 \mathrm{~cm}$, and peaty $<50 \mathrm{~cm}$ and cultivated only in the middle of the dry season when the ground water level has shrunk. In the wet season deep lebak is dominated by plants of natural waters, such as the lotus or teratai (the fruit is useful as a snack food), eceng gondok (usually used for handicrafts materials), water grass, keman (a type of putri malu that lives in water and is used as an ingredient side dish or vegetables at meals), and other wild plants.

Middle lebak is a part swampy area located lower than levee lebak and usually planted at the beginning of the dry season in order to make the surface of the water had receded for rice. It is flooded 3-6 months/year, and water level $50-100 \mathrm{~cm}$.

Table 1

Lebak Swamp Typology di Jakabaring Before landfilling*I

\begin{tabular}{llll}
\hline \multicolumn{1}{c}{ Types } & Status & Utilized by farmers & \multicolumn{1}{c}{ Locations } \\
Lebak lebung & $\begin{array}{l}\text { Relatively } \\
\text { static } \\
\text { Leep lebak }\end{array}$ & $\begin{array}{l}\text { Fishery, freshwater } \\
\text { resource }\end{array}$ & In a deep depressions (valley) \\
dynamic & Freshwater resource & Located next to the flood plains and \\
Middle lebak & Rice fields & $\begin{array}{l}\text { Lepressions } \\
\text { In flood plains and river valleys }\end{array}$ \\
Levee lebak & $\begin{array}{l}\text { Dynamic } \\
\text { Dynamic }\end{array}$ & Rice fields & $\begin{array}{l}\text { On the river levee, valley and flat } \\
\text { topography }\end{array}$ \\
Dry land & $\begin{array}{l}\text { Very } \\
\text { dynamic } \\
\text { Relatively } \\
\text { static }\end{array}$ & $\begin{array}{l}\text { Rice fields and } \\
\text { settlement } \\
\text { Agricultural and } \\
\text { settlement }\end{array}$ & $\begin{array}{l}\text { Alluvial plains and flat topography } \\
\text { Away from river levee and } \\
\text { topography }>1.5 \mathrm{~m} \text { above sea level }\end{array}$
\end{tabular}

Source: */ It was measured in the fields and supported by land use map (1:250,000 scale), Landsat, 2016., Google map, 2017., as well as field survey, (2017) 
Levee lebak is defined as similar with shallow lebak. It is differentiated that levee lebak is flooded $<3$ months/years, water level $25-50 \mathrm{~cm}$ and dry in the dry season. This swampy area is planted with rice in wet season and will be dry in the dry season. It is mostly located on the levee and the river valley and flat topography.

Shallow lebak is a part of swampy area planted to rice during the wet season. It is inundated only in wet season $(<$ 3 months/years), water level $<25 \mathrm{~cm}$, and dries in the dry season. Shallow lebak was being extremely dynamic meaning that regional development will directly influence the shallow lebak area. Direct impact of the regional development will increase sedimentation resulting in the total area flooded in riverbank is widespread. Because of its very dynamic, then the extent of their area can most small or very large. Compared with deep lebak and lebak lebung because of the permanent inundation of typologies, they are less dynamic than shallow lebak.

Dry land (Palembang local language is called the Tanah Nyurung) is partly swampy area that during the wet and dry season it is dry and flooded potential during at the wet season annually 5-10 years as well as serves as a place for living and to farm, especially subsistence agriculture. Dry land is generally located on the right or left side or in river center or general waters. The dry land in the river center or open waters is named as "pulau", according to local language) and functions as agricultural fields, namely rice fields or cereals.

There is a small part of Jakabaring area which is not touched by human activity, did not function as rice fields and covered with natural vegetation and it is called as lebak kumpai. Lebak kumpai can be divided into two parts, namely rawang forest and lebak rawang. Rawang forest is entirely untouched by human hands and is still a native habitat and vegetation is dominated by trees. The main functions of rawang forest as a place for fishing and looking for gum rosin (damar). Lebak rawang is a swampy area and dominated by kumpai shrubs and no trees. In general, the vegetation type was dominated by kumpai or prumpung or other types of grasses. Lebak rawang is utilized as cattle pasture and swamp buffalo and looking for raw materials of the mat making. Due to Jakabaring area is adjacent to the Palembang city, the pressure of population and economic development, then gradually Jakabaring area was experiencing land conversion and done by landfilling started in 1989. All this land conversion has changed Jakabaring into a form that is totally different from its initial condition before 1970 .

\section{Comparison of Lebak Swamp Typolo- gies before and after Landfilling}

Before landfilling in 1988, approximately 2,459 ha $(91.06 \%)$ of Jakabaring area consists of lebak swamp covering shallow lebak to lebak lebung, whereas the dry land was around 241 ha $(8.94 \%)$. At that time, the most widespread is middle lebak ( $24.21 \%)$, followed by deep lebak $(22.75 \%)$ and lebak lebung (20.31\%), levee lebak $(13.36 \%)$ and shallow lebak (10.43\%). At that time this area was considered as less economical area for all economic activities, including residential, industrial and others (Table 2).

After landfilling or existing condition, the typology composition of lebak swamp has changed significantly. Dry land area has increased becoming 1,964 ha $(72.73 \%)$, while the lebak swamp rest is only about 736 ha $(27.27 \%)$ consisting of shallow lebak 380.97 ha (14.11\%), deep lebak (127.71 ha $(4.73 \%)$, levee lebak 87.21 ha $(3.23 \%)$, middle lebak 82.89 ha $(3.07 \%)$ and lebak lebung only 57.51 ha $(2.13 \%)$.

Composition changes in lebak swamp typology impact directly on the economic activities of the community, private sectors and industry. If further analysis that acreages of deep lebak and lebak lebung is less than $10 \%$, this is negatively affecting the overall area because this area is susceptible or vulnerable to surface water overflow, i.e. overflow of Musi River water and excess of rain water. As we know that 
Table 2

Acreages of Lebak Swamp Areas before and after Landfilling

\begin{tabular}{|c|c|c|c|c|}
\hline \multirow[t]{2}{*}{ Types } & \multicolumn{2}{|c|}{ Before landfilling $(1988)^{\star}$} & \multicolumn{2}{|c|}{ Existing conditions (2017) } \\
\hline & ha & $\%$ & ha & $\%$ \\
\hline Lebak lebung & 548.37 & 20.31 & 57.51 & 2.13 \\
\hline Deep lebak & 614.25 & 22.75 & 127.71 & 4.73 \\
\hline Middle lebak & 653.67 & 24.21 & 82.89 & 3.07 \\
\hline Levee lebak & 360.72 & 13.36 & 87.21 & 3.23 \\
\hline Shallow lebak & 281.61 & 10.43 & 380.97 & 14.11 \\
\hline Dry land & 241.38 & 8.94 & $1,963.71$ & 72.73 \\
\hline Total & 2700 & 100 & 2700 & 100 \\
\hline
\end{tabular}

Source: ${ }^{*} /$ It was measured in the fields and supported by land use map (1:250,000 scale), Landsat, 2016., Google map, 2017., as well as field survey, (2017)

Table 3

Changing Soil Orders before and after Landfilling

\begin{tabular}{lcccc}
\hline \multirow{2}{*}{ Soil Orders } & \multicolumn{2}{c}{ Before landfilling $(1988)^{*} /$} & \multicolumn{2}{c}{ Existing conditions (2017) } \\
\cline { 2 - 5 } & ha & $\%$ & ha & $\%$ \\
\hline Entisols & 824.58 & 30.54 & $2,165.67$ & 80.21 \\
Inceptisols & 549.18 & 20.34 & 338.85 & 12.55 \\
Gelisols & 456.57 & 16.91 & 114.75 & 4.25 \\
Histosols & 869.67 & 32.21 & 80.73 & 2.99 \\
\hline Total & 2,700 & 100.00 & 2,700 & 100.00 \\
\hline Source: */ It was measured in the fields and supported by land use map (1:250,000 scale),
\end{tabular}

Landsat, 2016., Google map, 2017., as well as field survey, (2017)

main function of deep lebak and lebak lebung are acting as water catchment areas during the wet season or reservoir water especially in the dry season. Ideal conditions of Jakabaring have lebak lebung and deep lebak minimum 810 ha $(30 \%)$ of the total area (2,700 ha) landfilled.

\section{Lebak Swamp Soils before and after Landfilling}

Generally lebak swamp in Jakabaring is dominated by four major orders, i.e. orders of Entisols, Inceptisols, Gelisols and Histosols. There are some significant differences between soil orders before landfilling and after landfilling (existing conditions). Before landfilling, dominant soil orders were Histosols and Entisols covering around 869.67 ha $(32.21 \%)$ and 824.58 ha $(30.54 \%)$ and Inceptisols and Gelisols covered only around 549.18 ha $(20.34 \%)$ and 456.57 ha $(16.91 \%)$ respectively. Based on its dominance, soil orders were found i.e. Histosols, Entisols, Inceptisols and Gelisols (Table 3).

However these soil orders have changed dramatically after landfilling with dominance as follows: Entisols occupy the highest around 2,165.67 ha $(80.21 \%)$, Inceptisols are almost 338.85 ha $(12.55 \%)$, Gelisols cover an area of 114.75 ha $(4.25 \%)$ and the most minimum position is showed by Histosols only around 80.73 ha $(2.99 \%)$. Composition changes of soil orders effect generally to land suitability and land capability for supporting agricultural production.

Entisols area characterized by no differentiation horizon and means that soils are still undeveloped. Jakabaring area is dominated by this soil order around $2,165.67$ ha $(80.21 \%)$ as the landfilling results. Before landfilling Entisols were found only around $30.54 \%$. This expansion is due to the process of landfilling.

Inceptisols are determined by weak horizon differentiation, but Gelisols belong to highly developed soils. Histosols are showed by accumulation of organic materials with its thickness at least $30 \mathrm{~cm}$. Before landfilling fourth soil orders were relatively balanced and after landfilling Gelisols and Histosols were buried by landfilling and replaced by Entisols. Gelisols and Histosols are generally found in deep lebak and lebak lebung. 
Table 4

Potency of Rice Production before and after Landfilling *I

\begin{tabular}{|c|c|c|c|}
\hline Parameters & $\begin{array}{l}\text { Before landfilling } \\
(1988)^{*} /\end{array}$ & $\begin{array}{l}\text { Existing condition } \\
\text { (2016) }\end{array}$ & $\begin{array}{l}\text { Prediction } \\
\text { (2025) }\end{array}$ \\
\hline $\begin{array}{l}\text { Planting area (ha) } \\
\text { Total rice production (ton }\end{array}$ & $1,296(48.00 \%)$ & $202.50(7.50 \%)$ & $\begin{array}{l}(20) \\
0 \\
0\end{array}$ \\
\hline $\begin{array}{l}\text { MDR/year) } \\
\text { Farmer's household number } \\
\text { (KK) }\end{array}$ & 3,240 & 506.25 & 0 \\
\hline $\begin{array}{l}(\mathrm{KK}) \\
\text { Source: */ It was measure } \\
\text { Landsat, 2016., C }\end{array}$ & $\frac{353}{d s \text { and }}$ & 120 & \\
\hline
\end{tabular}

\section{Rice Production Potency}

Lebak swamp typology likely cultivated by farmers to grow rice is shallow lebak, levee lebak and middle lebak. Other lebak typologies are technically problematic because farmers have some difficulty to manage water overflow and they cultivate deep lebak and lebak lebung for fishery. Therefore acreages of planting area before landfilling were 1,296 ha $(48 \%)$, but in the existing conditions the planting area potency decreased sharply only around 551.07 ha $(20.41 \%)$. Most of rice planting area was abandoned; the real planting area was only about 202.50 ha $(7.50 \%)$.

If the average rice production of lebak swamp before landfilling was around 2.50 tons of milled dry rice (MDR)/ha/year, thus total rice production was approximately 3,240 tons MDR/year. In existing condition the rice production potency was only remaining 506.25 tons MDR/year. This amount continued to decrease due to intensive land conversion of agriculture to non-agriculture purposes. By 2025 it is estimated there is not found rice fields and probably farmer profession is no longer found in the research area (Table 4).

It means that Jakabaring area cannot be mentioned as lebak swamp or agricultural land as happened before landfilling (1988). In accordance with population pressure and economic development, farmers in Jakabaring are displaced to other places due to agricultural land unavailability and government support for activities agriculture is also minimal. Moreover government wanted to develop this area as international sport centers, residential, industry, recreation areas and any others.

\section{CONCLUSIONS}

Lebak swamp in Jakabaring can be divided into six typologies, namely lebak lebung, deep lebak, middle lebak, levee lebak, shallow lebak and dry land. After landfilling, dry land area has increased becoming 1,964 ha $(72.73 \%)$, while other lebak swamp is only about 736 ha $(27.27 \%)$ consisting of shallow lebak 380.97 ha (14.11\%), deep lebak (127.71 ha (4.73\%), levee lebak 87.21 ha (3.23\%), middle lebak 82.89 ha $(3.07 \%)$ and lebak lebung only 57.51 ha $(2.13 \%)$. Before landfilling, the dominant soil orders were found i.e. Histosols, Entisols, Inceptisols and Gelisols. It changed dramatically after landfilling with dominance as follows: Entisols, Inceptisols, Gelisols and Histosols. Total rice production was around 3,240 tons milled dry rice (MDR)/year before landfilling and in existing condition its potency remains only 506.25 tons MDR/year.

\section{ACKNOWLEDGEMENTS}

The authors would like to thank the local farmers who kindly gave their time to give us the detailed data and information for the research. Thanks and appreciations also are addressed to the Sriwijaya University that financially support this research through "Penelitian Unggulan Profesi" $\mathrm{Nr}$ 985/UN9.3.1/LPPM/2016 and the Agriculture Faculty who has given technical support and allow us to publish this paper.

\section{REFERENCES}

Adriani, D., I. Zahri, E. Wildayana, Maryadi, M. Hamzah and Yulius. (2018). Farmer's Welfare in Telang's Integrated Independent City: Lesson 
Learned From Migrant and Local Farmers in Tidal Land, South Sumatera. IOP Conf. Series: Earth and Environmental Science 122, 1-7.

Armanto, M.E. (2014). Spatial Mapping for Managing Oxidized Pyrite (Fes2) in South Sumatra Wetlands, Indonesia. Journal of Wetlands Environmental Managements, 2(2), 6-12.

Armanto, M.E., Adzemi, M.A., Wildayana, E. and Imanudin, M.S. (2013). Land Evaluation For Paddy Cultivation in The Reclaimed Tidal Lowland in Delta Saleh, South Sumatra, Indonesia. Journal of Sustainability Science and Management, 8(1), 32-42.

Junedi, H., Armanto, M.E., Bernas, S.M. and Imanudin, M.S. (2017). Changes to Some Physical Properties Due to Conversion of Secondary Forest of Peat Into Oil Palm Plantation. Sriwijaya Journal of Environment, 2(3),76-80.

Ningsih, R., Sjarkowi, F., Sufri, M., Adriani, D. and Wildayana, E. (2017). Analysis of Remoteness Effect of Indigenous Coconut (Cocosnucifera I.) Commodity on Farmers Profit at Tidal Lowland Area of Jambi Province-Indonesia. Sriwijaya Journal of Environment, 2(3), 88-92.

Sarno, R.A. Suwignyo, Z. Dahlan, Munandar, M.R. Ridho, N. Aminasih, Harmida, M.E. Armanto and E. Wildayana. (2017). The Phenology of Sonneratia alba J. Smith in Berbak and Sembilang National Park, South Sumatra, Indonesia. Biodiversitas, 18(3), 909-915.

Sjarkowi, F., Arbain, A., Armanto, M.E., Santoso, U., Arjuna, J., Rifardi, Setiawan, A., Syahrul, J., Khairijon and Azizah. 2007. Environmental Quality of Sumatra Island. (2007). Center for Regional Environmental Management, State Ministry for Environment, Pekanbaru, Riau, ISBN. 978-602-8107-00-6. p. 393.
Soil Survey Staff. (2014). Keys to Soil Taxonomy, 12th USDA-Natural Resources Conservation Service, Washington, DC.

Wildayana, E. (2014). Formulating Oil Palm Investment Decision in Tidal Wetlands of South Sumatra, Indonesia. Journal of Wetlands Environmental Managements, 2(2), 30-36.

Wildayana, E. (2015). Formulating Rice Fields Conversion Control to Oil Palm Plantations in Tidal Wetlands of South Sumatra, Indonesia. Journal of Wetlands Environmental Managements, 3(2), 72-78.

Wildayana, E. (2017). Challenging Constraints of Livelihoods for Farmers on the South Sumatra peatlands, Indonesia. Bulg. J. Agric. Sci., 23(6), 894-905.

Wildayana, E. (2018a). Dynamics of Landuse Changes and General Perception of Farmers on South Sumatra Wetlands. Bulg. J. Agric. Sci., 24(2), 180-188.

Wildayana, E. (2018b). Utilizing Non-timber Extraction of Swamp Forests Over Time for Rural Livelihoods. Journal of Sustainable Development, 11(2), 52-62.

Zahri, I., Sabaruddin, M.U. Harun, D. Adriani and E. Wildayana. (2018). Comparing Rice Farming Appearance of Different Agroecosystem in South Sumatra, Indonesia. Bulg. J. Agric. Sci., 24(4), 189-198. 